\title{
Speciation of methylmercury in rice grown from a mercury mining area
}

\author{
Lu Li $^{\text {a,b,c }}{ }^{\text {, Feiyue Wang }}{ }^{\text {a,b,* }}$, Bo Meng ${ }^{d}$, Marcos Lemes ${ }^{\text {a,b }}$, Xinbin Feng ${ }^{d}$, Guibin Jiang ${ }^{c}$ \\ ${ }^{a}$ Department of Environment and Geography, University of Manitoba, Winnipeg, MB R3T 2N2, Canada \\ ${ }^{\mathrm{b}}$ Department of Chemistry, University of Manitoba, Winnipeg, MB R3T 2N2, Canada \\ ${ }^{\mathrm{C}}$ State Key Laboratory of Environmental Chemistry and Ecotoxicology, Research Center for Eco-Environmental Sciences, \\ Chinese Academy of Sciences, P.O. Box 2871, Beijing100085, PR China \\ ${ }^{\mathrm{d}}$ State Key Laboratory of Environmental Geochemistry, Institute of Geochemistry, Chinese Academy of Sciences, \\ 46 Guanshui Road, Guiyang, Guizhou 550002, PR China \\ Methylmercury in uncooked rice occurs predominantly as methylmercury-L-cysteinate, which is effectively removed during the cooking process.
}

\section{A R T I C L E I N F O}

\section{Article history:}

Received 29 March 2010

Received in revised form

17 June 2010

Accepted 22 June 2010

\section{Keywords:}

Rice

Mercury

Methylmercury

Speciation

Risk assessment

Enzymatic hydrolysis

ICP-MS

LC

\begin{abstract}
A B S T R A C T
Monomethylmercury $\left(\mathrm{CH}_{3} \mathrm{Hg}^{+}\right.$and its complexes; MeHg hereafter) is a known developmental neurotoxin. Recent studies have shown that rice (Oryza sativa L.) grain grown from mercury (Hg) mining areas may contain elevated MeHg concentrations, raising concerns over the health of local residents who consume rice on a daily basis. An analytical method employing high performance liquid chromatography (HPLC) inductively coupled plasma mass spectrometry (ICP-MS) following enzymatic hydrolysis was developed to analyze the speciation of $\mathrm{MeHg}$ in uncooked and cooked white rice grain grown from the vicinity of a Hg mine in China. The results revealed that the $\mathrm{MeHg}$ in the uncooked rice is present almost exclusively as $\mathrm{CH}_{3} \mathrm{Hg}$-L-cysteinate $\left(\mathrm{CH}_{3} \mathrm{HgCys}\right)$, a complex that is thought to be responsible for the transfer of MeHg across the blood-brain and placental barriers. Although cooking does not change the total $\mathrm{Hg}$ or total $\mathrm{MeHg}$ concentration in rice, no $\mathrm{CH}_{3} \mathrm{HgCys}$ is measurable after cooking, suggesting that most, if not all, of the $\mathrm{CH}_{3} \mathrm{HgCys}$ is converted to other forms of $\mathrm{MeHg}$, the identity and toxicity of which remain elusive.
\end{abstract}

(c) 2010 Elsevier Ltd. All rights reserved.

\section{Introduction}

Monomethylmercury $\left(\mathrm{CH}_{3} \mathrm{Hg}^{+}\right.$and its complexes; MeHg hereafter) is considered the most toxic form of mercury ( $\mathrm{Hg}$ ) because of its capability of biomagnification along food chains and its developmental neurotoxicity (Mergler et al., 2007; WHO, 1990). It is well established that consumption of fish, fish products and marine mammal tissues is the major MeHg exposure pathway to most human populations (Clarkson, 1998; Lockhart et al., 2005; WHO, 1990). However, recent studies have shown that rice grown from local areas near $\mathrm{Hg}$ mines or mine tailings could contain elevated concentrations of $\mathrm{MeHg}$ (Feng et al., 2008; Horvat et al., 2003; Zhang et al., 2010). For instance, the MeHg concentration in white rice (i.e., hull- and bran-removed; also known as polished rice) grown at abandoned $\mathrm{Hg}$ mining areas in Guizhou Province, China, ranged from 1.6 to $174 \mu \mathrm{g} \mathrm{kg}^{-1}$ (dry weight; average: $25 \mu \mathrm{g} \mathrm{kg}^{-1}$ )

\footnotetext{
* Corresponding author.

E-mail address: wangf@ms.umanitoba.ca (F. Wang).
}

(Qiu et al., 2008). Although this concentration range is lower than the generally accepted safe consumption threshold for $\mathrm{Hg}$ in fish (e.g., $200 \mu \mathrm{g} \mathrm{kg}^{-1}$ (wet weight) by Health Canada (CFIA, 2001)), when considering that local residents consume rice or rice products almost every meal, the human $\mathrm{MeHg}$ intake from rice in this region averaged $0.26 \mu \mathrm{g} \mathrm{kg}^{-1}$ of body weight per day (Qiu et al., 2008), exceeding the dietary reference dose (RfD) for $\mathrm{MeHg}$ recommended by U.S. EPA ( $0.1 \mu \mathrm{g} \mathrm{kg}^{-1}$ body weight per day; USEPA, 1992). Indeed, a statistically significant relationship has been reported between the human hair $\mathrm{Hg}$ levels and estimated rice $\mathrm{MeHg}$ intake for the local residents, confirming rice is a new $\mathrm{MeHg}$ exposure pathway in this mining region (Feng et al., 2008).

As a soft Lewis acid, free $\mathrm{CH}_{3} \mathrm{Hg}^{+}$ions do not occur at any significant concentration in the intracellular environment due to their high affinity to the thiol groups $(-\mathrm{SH})$ which are soft Lewis bases. The formation of $\mathrm{MeHg}$ complexes with thiol-containing molecules, such as cysteine, glutathione, homocysteine and albumin, plays a key role in the transport and distribution of $\mathrm{MeHg}$ in biota. For example, while binding with glutathione may act as a detoxifying pathway for $\mathrm{MeHg}$, binding with L-cysteine has been suggested to be responsible for the transfer of $\mathrm{MeHg}$ across the 
blood-brain and placental barriers (Clarkson, 1993; SimmonsWillis et al., 2002). Therefore, knowing the total concentration of MeHg may not be sufficient for the understanding of its bioavailability, metabolism and toxicity; instead, speciation analysis of MeHg in biological samples is needed.

Harris et al. (2003) provided the first analytical evidence for the dominance of $\mathrm{MeHg}$-thiol complexes in fish muscle based on synchrotron-aided X-ray absorption spectroscopy. By using high performance liquid chromatography - inductively coupled plasma mass spectrometry (HPLC-ICP-MS), Lemes and Wang (2009) was the first to report that $\mathrm{MeHg}$ in a dogfish muscle was present almost exclusively as $\mathrm{CH}_{3} \mathrm{Hg}$-L-cysteinate. Here we report the first study on the speciation of $\mathrm{MeHg}$ in rice grains grown from a rice paddy near a $\mathrm{Hg}$ mine, and the effect of cooking on $\mathrm{MeHg}$ speciation in rice.

\section{Materials and methods}

\subsection{Reagents and standards}

All the chemicals were of ACS grade or higher, unless otherwise specified. Methanol, acetonitrile, acetic acid (Optima grade), ammonium hydroxide, potassium hydroxide, and ammonium acetate (HPLC grade) were from Fisher Scientific, L-cysteine ( $>98 \%$ ), L-glutathione (reduced form, 98\%), trypsin, pepsin, protease K, chymotrypsin, and $\alpha$-amylase from Sigma, $\mathrm{CH}_{3} \mathrm{HgOH}$ ( $1 \mathrm{~mol} \mathrm{~L}^{-1}$ stock solution) from Alfa Aesar, and methanesulfonic acid (MSA) (>99.9\%) from Fluka. Inorganic Hg and Au stock solutions (100 $\mathrm{mg} \mathrm{L}^{-1}$ ) were from Spex Certiprep (Claritas PPT grade). Ultrapure deionized water ( $>18.2 \mathrm{M} \Omega \mathrm{cm}$; Milli-Q Element) was used as the laboratory water. Except for the process of rice cooking and enzymatic hydrolysis, all the sample preparation and analysis were carried out in Class 100-1000 cleanrooms in the metal-free Ultra-Clean Trace Elements Laboratory (UCTEL) at the University of Manitoba.

$\mathrm{CH}_{3} \mathrm{Hg}$-L-cysteinate $\left(\mathrm{CH}_{3} \mathrm{HgCys}\right)$ and $\mathrm{CH}_{3} \mathrm{Hg}$-L-glutathionate $\left(\mathrm{CH}_{3} \mathrm{HgGlu}\right)$ were synthesized according to Lemes and Wang (2009). The mixed working solutions of various concentrations were made by stepwise dilution from the stock solution and adjusted to $\mathrm{pH} 5$ before being analyzed. Acetate buffer solution $(50 \mathrm{mM}, \mathrm{pH}=8.0)$ was prepared daily from $\mathrm{NH}_{4} \mathrm{Ac}$ and $\mathrm{NH}_{4} \mathrm{OH}$.

\subsection{Rice sample and sample preparation}

The MeHg-elevated rice (Oryza sativa L.) sample was collected from the vicinity of the Guoxi Hg mine in Tongren, Guizhou Province, China, on September 7, 2006. After the hull- and bran were removed, the white rice grains were ground to fine powders using an agate pestle and mortar. The total $\mathrm{Hg}\left(\mathrm{Hg}_{\mathrm{T}}\right)$ and total $\mathrm{MeHg}$ $\left(\mathrm{MeHg}_{\mathrm{T}}\right)$ in the white rice sample were $289.3 \mu \mathrm{g} \mathrm{kg}^{-1}$ and $124.5 \mu \mathrm{g} \mathrm{kg}^{-1}$ (dry weight) respectively, as reported earlier (Qiu et al., 2008). Both uncooked and cooked white rice were analyzed in this work. As shown below, cooking does not change $\mathrm{Hg}_{\mathrm{T}}$ or $\mathrm{MeHg}_{\mathrm{T}}$ concentrations in the rice.

\subsection{Enzymatic hydrolysis}

Enzymatic hydrolysis was used to extract various MeHg species from the uncooked and cooked white rice samples based on a procedure developed for $\mathrm{MeHg}$ speciation analysis for fish muscle (Lemes and Wang, 2009). Several enzymes including trypsin, pepsin, protease $\mathrm{K}$, chymotrypsin, $\alpha$-amylase were tested for optimal performance with respect to the recovery of the $\mathrm{Hg}_{\mathrm{T}}$ and $\mathrm{MeHg}_{\mathrm{T}}$ concentrations and the preservation of $\mathrm{MeHg}$ speciation.

For the MeHg extraction of uncooked rice with trypsin, about $200 \mathrm{mg}$ of the ground white rice sample were weighed into a $15-\mathrm{mL}$ polypropylene centrifuge tube, to which $5 \mathrm{~mL}$ of the acetate buffer solution $(\mathrm{pH}=8.0)$ and $5 \mathrm{mg}$ of trypsin were added. For the MeHg extraction of the cooked white rice, $100 \mathrm{mg}$ of the ground uncooked rice sample were placed in a 15-mL polypropylene centrifuge tube to which $5 \mathrm{~mL}$ of the acetate buffer solution was added. The tube was then heated in a boiling water bath for $20 \mathrm{~min}$. Upon cooling to the room temperature, $5 \mathrm{mg}$ of trypsin were added into the extraction solution. In both cases, the tubes were capped and placed on a tube rotator with rotisserie (VWR) at $20 \mathrm{rpm}$ inside a $37^{\circ} \mathrm{C}$ Isotemp oven (Fisher Scientific) for $24 \mathrm{~h}$. To avoid any possible photochemical degradation, the extraction was carried out in the dark. The extractant was centrifuged for $30 \mathrm{~min}$, and the supernatant was filtered through a syringe filter with a $0.45-\mu \mathrm{m}$ membrane (Millex-HV; Millipore). Approximate $1 \mathrm{~mL}$ of the supernatant was taken for $\mathrm{Hg}_{\mathrm{T}}$ measurement. Aliquots of supernatant from the uncooked rice sample and cooked rice sample were diluted with ultrapure water to minimize the matrix interference with the speciation analysis (Lemes and Wang, 2009). The diluted sample was adjusted to $\mathrm{pH}=5$ with a $4 \mathrm{M}$ acetic acid (Lemes and Wang, 2009) before being injected for MeHg speciation analysis.

Extraction of the rice samples with other enzymes followed a similar procedure, except the $\mathrm{pH}$ of the extraction solution was adjusted to 2.0 when using pepsin and 6.9 when using $\alpha$-amylase.

\subsection{Analysis}

The analysis of $\mathrm{Hg}_{\mathrm{T}}$ and MeHg speciation was done by HPLC-ICP-MS on an Agilent 1200 series HPLC coupled with a Perkin Elmer DRC II ICP-MS. The effluent from the HPLC column was connected via PEEK tubing to a PFA $400 \mu \mathrm{L}$ self-aspirating micro-nebulizer (Elemental Scientific Inc.) and a quartz cyclonic spray chamber (Perkin Elmer). A quartz microinjector ( $0.8 \mathrm{~mm}$ I.D.; Perkin Elmer) was used to prevent high organic solvent load from entering the plasma which could destabilize the plasma. The detailed instrumentation was described elsewhere (Lemes and Wang, 2009). The instrument performance was optimized daily for the plasma power, nebulizer gas flow rate, lens voltage and autolens voltage. The operational parameters are shown in Table 1. Data collection and processing was carried out with Chromera (version 1.1, Perkin Elmer). Identification of the species was done based on retention time and standard addition, and quantification were done by measuring the peak area after calibration with known $\mathrm{MeHg}$ standards. When analyzing for $\mathrm{Hg}_{\mathrm{T}}$, the analytical column was bypassed. The detection limit (DL) for $\mathrm{Hg}_{\mathrm{T}}$ (calculated as 3 times standard deviation of the blank solution at $\mathrm{pH}=5$ ) was $0.11 \mu \mathrm{g} \mathrm{L}^{-1}$. QA/QC was achieved by using triplicates, method blanks and matrix spikes. The relative percentage difference was $<5 \%$ in triplicate samples. The recovery on matrix spikes of $\mathrm{CH}_{3} \mathrm{HgCys}$ in the rice samples was $95.6 \pm 3.2 \%(n=3)$. All the $\mathrm{Hg}$ and $\mathrm{MeHg}$ concentrations are reported in terms of $\mathrm{Hg}$.

For $\mathrm{MeHg}_{\mathrm{T}}$ analysis, $0.3-0.5 \mathrm{~g}$ of rice sample (cooked or uncooked) was digested using a $\mathrm{KOH}-$ methanol extraction technique (Liang et al., 1994, 1996) and determined by gas chromatography - cold vapour atomic fluorescence spectroscopy (GC-CVAFS; Brooks Rand Model III) according to U.S. EPA method 1630 (USEPA 2001). The DL was $2 \mathrm{ng} \mathrm{kg}^{-1}$ for $\mathrm{MeHg}_{\mathrm{T}}$. The relative standard deviation for analysis of triplicate samples was $\leq 8.1 \%$. Recoveries for the certified reference material TORT-2 (National Research Council of Canada) ranged from 87 to $91 \%$.

\section{Results}

\subsection{Optimization of enzymatic hydrolysis}

Selection of the enzyme is of crucial importance in enzymatic hydrolysis for $\mathrm{Hg}$ speciation analysis, as the ideal enzyme should extract the $\mathrm{Hg}$ from the rice sample efficiently yet preserve the in vivo speciation information (Lemes and Wang, 2009). When extracting a mixed $\mathrm{CH}_{3} \mathrm{HgCys}$ and $\mathrm{CH}_{3} \mathrm{HgGlu}$ standard solution, $\alpha$-amylase provoked the transformation of $\mathrm{CH}_{3} \mathrm{HgGlu}$ to $\mathrm{CH}_{3} \mathrm{HgCys}$, while protease $\mathrm{K}$ and chymotrypsin converted $\mathrm{CH}_{3} \mathrm{HgCys}$ to $\mathrm{CH}_{3} \mathrm{HgX}\left(\mathrm{X}=\right.$ small inorganic ligands, such as $\mathrm{H}_{2} \mathrm{O}, \mathrm{OH}^{-}$or $\mathrm{Cl}^{-}$; Lemes and Wang, 2009) and some unidentified $\mathrm{Hg}$ compounds. Although pepsin maintained the peaks of $\mathrm{CH}_{3} \mathrm{HgCys}$ and $\mathrm{CH}_{3} \mathrm{HgGlu}$ in the standard solution, it resulted in colloidal extractant when applied to rice. In contrast, trypsin not only kept the speciation information of all the $\mathrm{MeHg}$ compounds tested in the standard solution (see Fig. S1 in the supporting information), but also yielded a pellucid extractant solution that was readily filterable. Therefore, trypsin was chosen as the enzyme for all the subsequent analysis.

The concentration of tryspin and extraction time were further optimized. As shown in Fig. 1A, no significant difference was found in the extraction efficiency for $\mathrm{Hg}_{\mathrm{T}}$ with different concentrations of

Table 1

Operating conditions for HPLC-ICP-MS.

\begin{tabular}{|c|c|}
\hline \multicolumn{2}{|l|}{ HPLC } \\
\hline Analytical column & $\begin{array}{l}\text { Luna C18(2) }(150 \mathrm{~mm} \times 4.60 \mathrm{~mm} \times 5 \mu \mathrm{m} \text {; } \\
\text { Phenomenex })\end{array}$ \\
\hline Guard column & $\begin{array}{l}\text { Luna } \mathrm{C} 18(2)(4 \mathrm{~mm} \times 3 \mathrm{~mm} \times 5 \mu \mathrm{m} \text {; } \\
\text { Phenomenex })\end{array}$ \\
\hline Mobile phase & $\begin{array}{l}2 \mathrm{mM} \text { MSA (pH 5) containing } 100 \mu \mathrm{g} \mathrm{L}^{-1} \mathrm{Au}: \\
\text { methanol : acetonitrile }=90: 7.5: 2.5(\mathrm{v} / \mathrm{v})\end{array}$ \\
\hline Flow rate & $1.0 \mathrm{ml} \mathrm{min}^{-1}$ \\
\hline Injection volume & $100 \mu \mathrm{L}$ \\
\hline \multicolumn{2}{|l|}{ ICP-MS } \\
\hline RF power & $1400 \mathrm{~W}$ \\
\hline Nebulizer & PFA $400 \mu \mathrm{L}$ self-aspirating micro-nebulizer \\
\hline $\begin{array}{l}\text { Nebulizer gas } \\
\text { flow rate }\end{array}$ & $\sim 0.62 \mathrm{~L} \mathrm{~min}^{-1}$ (optimized daily) \\
\hline Torch injector & $0.8 \mathrm{~mm}$ I.D. \\
\hline Analytical mode & Standard (non-DRC) \\
\hline Isotope monitored & ${ }^{202} \mathrm{Hg}$ \\
\hline
\end{tabular}



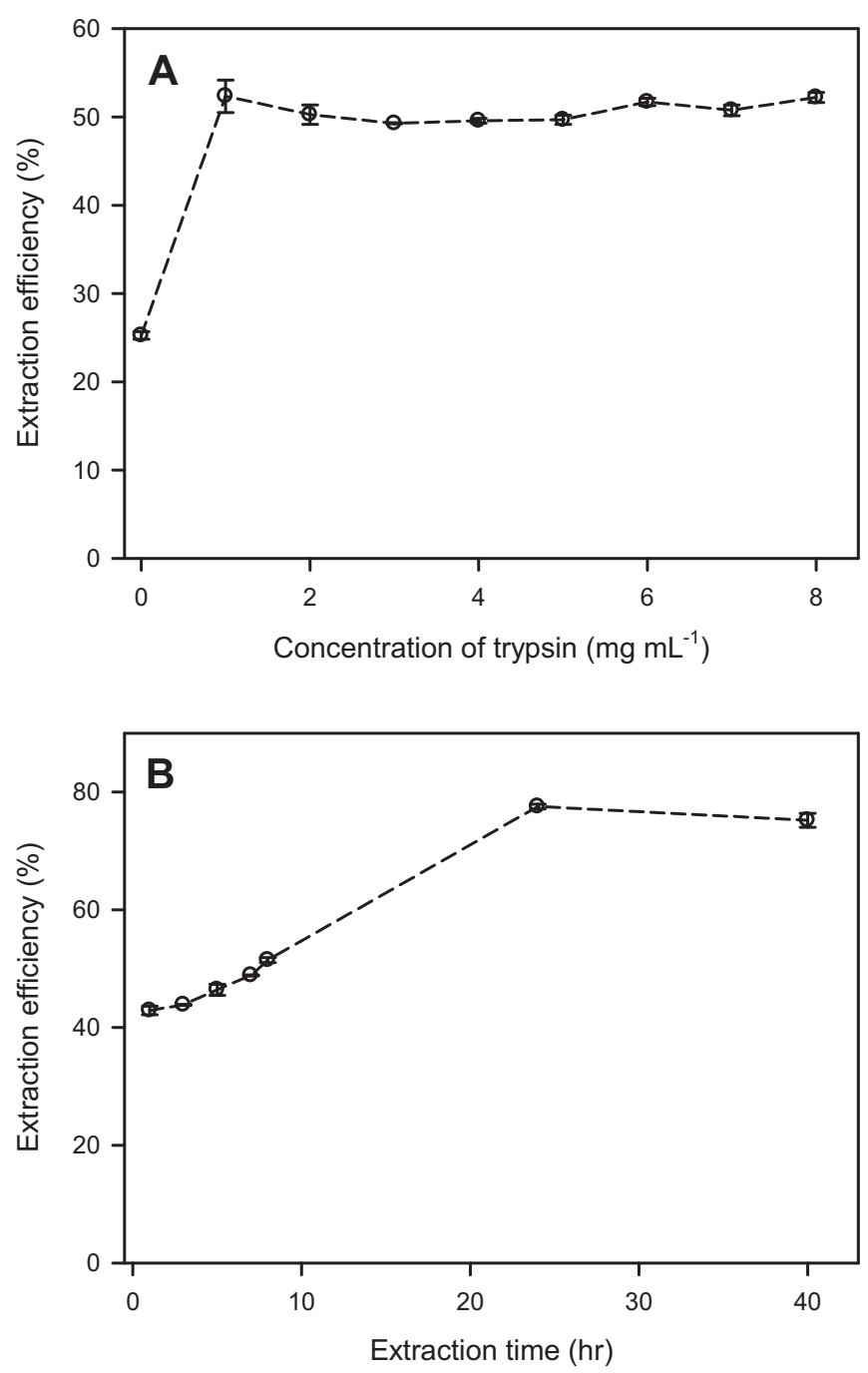

Fig. 1. A) Effect of the trypsin concentration on the efficiency of enzyme hydrolysis of uncooked white rice for total $\mathrm{Hg}(200 \mathrm{mg}$ rice in $5 \mathrm{~mL}$ acetate buffer after $8 \mathrm{~h}$ of extraction); B) Effect of extraction time on enzyme hydrolysis (200 mg rice in $5 \mathrm{~mL}$ acetate buffer with $1 \mathrm{mg} \mathrm{mL}^{-1}$ trypsin). Error bars show the standard deviation from three replicate measurements.

trypsin within the range $\left(1.0-8.0 \mathrm{mg} \mathrm{mL}^{-1}\right.$ for $200 \mathrm{mg}$ uncooked rice) studied. Therefore, $1.0 \mathrm{mg} \mathrm{mL}^{-1}$ trypsin was adopted for the subsequent extraction.

The effect of extraction time was studied using $200 \mathrm{mg}$ uncooked rice sample and $5 \mathrm{~mL} 0.05 \mathrm{M}$ acetate buffer $(\mathrm{pH}=8)$ containing $1.0 \mathrm{mg} \mathrm{mL}^{-1}$ trypsin. As shown in Fig. 1B, the extraction efficiency of $\mathrm{Hg}_{\mathrm{T}}$ increased linearly with the extraction duration within $24 \mathrm{~h}$ and then began to plateau. The optimum extraction time for trypsin extraction was determined to be $24 \mathrm{~h}$.

Under these optimized conditions for trypsin hydrolysis, the extraction efficiency for the uncooked rice sample was $77.3 \pm 3.1 \%$ $(n=3)$ for $\mathrm{Hg}_{\mathrm{T}}$ and $91.2 \pm 2.2 \%(n=3)$ for $\mathrm{MeHg}_{\mathrm{T}}$. The extraction efficiency for the cooked rice sample was $73.2 \pm 2.0 \%(n=3)$ for $\mathrm{Hg}_{\mathrm{T}}$. The slightly lower extraction efficiency of the cooked rice is likely due to its puffy, soft and sticky texture.

\section{2. $\mathrm{MeHg}$ speciation in the uncooked rice sample}

As shown in Fig. 2A, a sharp peak of $\mathrm{CH}_{3} \mathrm{HgCys}$ at the retention time of 2.6 min was evident in the extractant from the uncooked

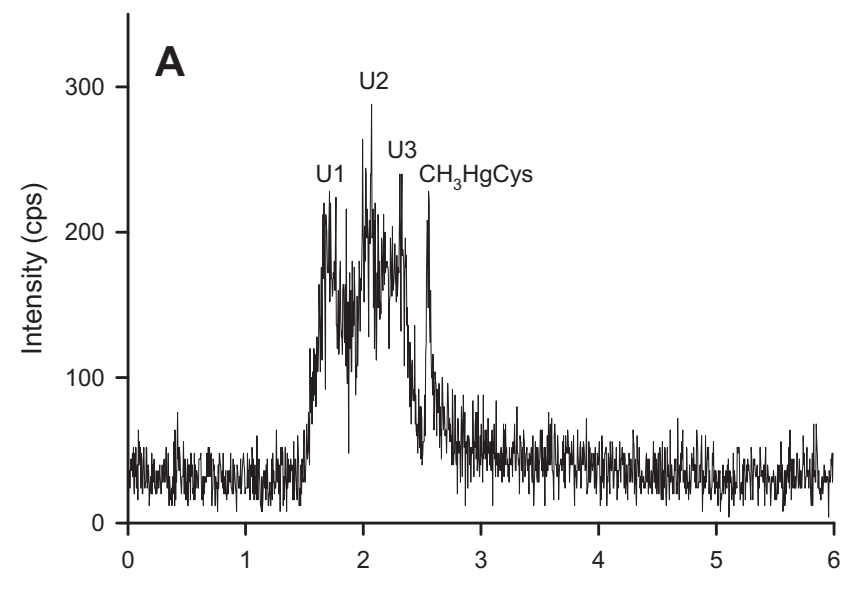

Retention time (min)

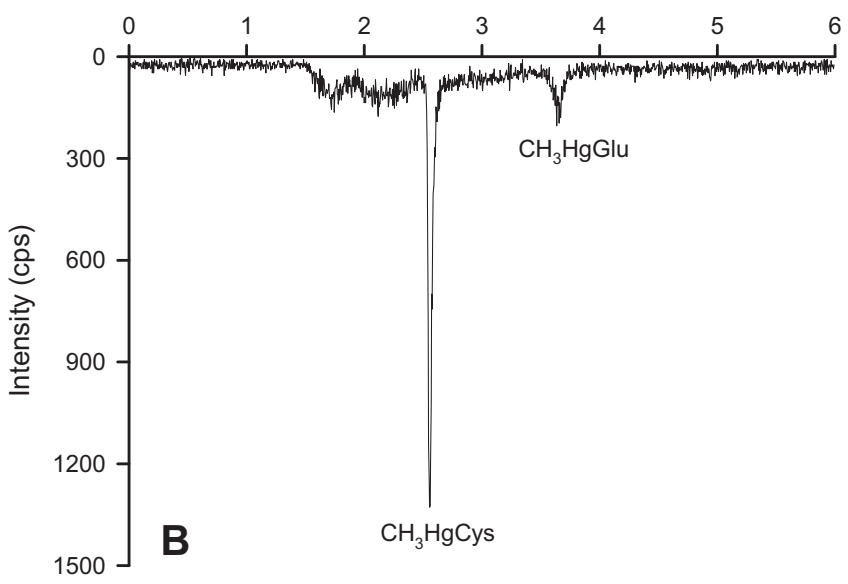

Fig. 2. Speciation analysis of uncooked white rice extractant using HPLC-ICP-MS. A) A chromatogram of the uncooked rice $(200 \mathrm{mg})$ extractant by trypsin hydrolysis (after $10 \times$ dilution); B) Chromatogram of the uncooked rice extractant (after $10 \times$ dilution) spiked with a $10 \mu \mathrm{g} \mathrm{L}^{-1}$ of $\mathrm{CH}_{3} \mathrm{HgCys}$ and $\mathrm{CH}_{3} \mathrm{HgGlu}$ standard solution.

rice sample (after $10 \times$ dilution). No measurable peaks of $\mathrm{CH}_{3} \mathrm{HgGlu}$ and $\mathrm{CH}_{3} \mathrm{HgX}$ were detected in the chromatogram. Based on the calibration curve (see Figure S2) and the peak area, the concentration of $\mathrm{CH}_{3} \mathrm{HgCys}$ in the uncooked rice was calculated to be $113.6 \pm 2.7 \mu \mathrm{g} \mathrm{kg}^{-1}(n=3)$, which agreed very well with the previously reported $\mathrm{MeHg}_{\mathrm{T}}$ concentration of $124.5 \mu \mathrm{g} \mathrm{kg}^{-1}$ for the same batch of the samples (Qiu et al., 2008).

As noted previously (Lemes and Wang, 2009), the dilution of the rice extractant before speciation analysis is necessary; otherwise matrix interference could be significant. This was demonstrated by a standard addition experiment. A $10 \mu \mathrm{g} \mathrm{L}^{-1}$ of mixed $\mathrm{CH}_{3} \mathrm{HgCys}$ and $\mathrm{CH}_{3} \mathrm{HgGlu}$ standard solution was spiked into the rice extractant with various dilution factors. The recovery of the standard was improved significantly with an increasing dilution ratio. When the uncooked rice extractant was diluted 10 fold, the recoveries of $\mathrm{CH}_{3} \mathrm{HgCys}$ and $\mathrm{CH}_{3} \mathrm{HgGlu}$ were $90.6 \%$ and $12.2 \%$, respectively (Fig. 2B). A similarly low recovery for $\mathrm{CH}_{3} \mathrm{HgGlu}$ was reported in enzymatic hydrolysis of fish muscle (Lemes and Wang, 2009); the reason remains unknown. Therefore, the current method is only applicable for biological samples where $\mathrm{MeHg}$ speciation is dominated by $\mathrm{CH}_{3} \mathrm{HgCys}$, which appears to be the case for both fish muscle (Lemes and Wang, 2009) and rice.

In addition to $\mathrm{CH}_{3} \mathrm{HgCys}$, the chromatogram of uncooked rice extractant (Fig. 2A) also shows the presence of at least 3 unknown peaks (U1, U2, U3) with retention times smaller than that of $\mathrm{CH}_{3} \mathrm{HgCys}$. Since the $\mathrm{CH}_{3} \mathrm{HgCys}$ concentration alone agreed well 
with the $\mathrm{MeHg}_{\mathrm{T}}$ concentration, and since no $\mathrm{HgX}$ peak (retention time $10.48 \mathrm{~min}$; data not shown) was evident, we ascribe these peaks to some yet-to-be-identified inorganic $\mathrm{Hg}$ complexes.

\subsection{MeHg speciation in the cooked rice sample}

Fig. 3 (in red) shows the chromatogram of the extractant (after $2 \times$ dilution) of a cooked rice sample. Different from the uncooked rice sample (in blue), no measurable peak of $\mathrm{CH}_{3} \mathrm{HgCys}$ was identified, suggesting that most of the $\mathrm{CH}_{3} \mathrm{HgCys}$ in the original uncooked rice was lost during the cooking process. At least two of the unknown Hg species (U1 and U2), however, remained after the cooking process.

To test the hypothesis that $\mathrm{CH}_{3} \mathrm{HgCys}$ degrades during the cooking process, a $107.2 \pm 0.9 \mu \mathrm{g} \mathrm{L}^{-1}(n=3) \mathrm{CH}_{3} \mathrm{HgCys}$ solution was "cooked" following the same process of cooking the rice. As shown in Fig. 4, the cooking process partially degraded $\mathrm{CH}_{3} \mathrm{HgCys}$ to $\mathrm{CH}_{3} \mathrm{HgX}$. Based on the peak areas, the concentration of $\mathrm{CH}_{3} \mathrm{HgCys}$ remaining in the cooked solution was $62.2 \pm 1.4 \mu \mathrm{g} \mathrm{L}^{-1}(n=3)$ and the concentration of $\mathrm{CH}_{3} \mathrm{HgX}$ was $39.8 \pm 2.1 \mu \mathrm{g} \mathrm{L}^{-1}(n=3)$. The sum of the two $\mathrm{Hg}$ species was $102.0 \pm 2.5 \mu \mathrm{g} \mathrm{L}{ }^{-1}(n=3)$, which agreed with the initial $\mathrm{CH}_{3} \mathrm{HgCys}$ concentration. No inorganic $\mathrm{Hg}$ and $\mathrm{Hg}^{0}$ were formed during the "cooking" of the $\mathrm{CH}_{3} \mathrm{HgCys}$ standard.

An independent test with a different batch of brown (i.e., only hull was removed) and white rice was further conducted to test the effect of cooking on the $\mathrm{MeHg}_{\mathrm{T}}$ concentration in rice. The results suggested that there was no statistically significant difference between the uncooked $(35.2 \pm 2.3 \mu \mathrm{g} \mathrm{kg}-1 ; n=4)$ and cooked $\left(33.5 \pm 2.2 \mu \mathrm{g} \mathrm{kg}^{-1} ; n=5\right)$ brown rice $(p=0.259 ; t$-test), and between uncooked (24.6 $\left.\pm 2.1 \mu \mathrm{g} \mathrm{kg}{ }^{-1}, n=5\right)$ and cooked $\left(23.9 \pm 1.4 \mu \mathrm{g} \mathrm{kg}^{-1}, n=5\right)$ white rice $(p=0.545)$. Similarly, no statistically significant difference was found between the $\mathrm{Hg}_{\mathrm{T}}$ concentration in the uncooked $(235.5 \pm 5.1 \mu \mathrm{g} \mathrm{kg}-1 ; n=4)$ and cooked $\left(236.5 \pm 10.7 \mu \mathrm{g} \mathrm{kg}^{-1} ; n=4\right)$ brown rice $(p=0.871)$, and between uncooked $\left(77.5 \pm 1.7 \mu \mathrm{g} \mathrm{kg}^{-1} ; n=4\right)$ and cooked $\left(78.5 \pm 1.9 \mu \mathrm{g} \mathrm{kg}^{-1}, n=4\right)$ white rice $(p=0.468)$.

\section{Discussion}

When exposing root and shoot sections of rice plants to MeHg in laboratory, Krupp et al. (2009) did not detect any MeHg complexes in the tissue extractants. They attributed the lack of the $\mathrm{MeHg}$ complexes to the formation of inorganic $\mathrm{Hg}$ complexes with



Fig. 3. MeHg speciation in the extractants of uncooked white rice (200 mg rice; after $10 \times$ dilution) and cooked rice (100 mg rice; after $2 \times$ dilution).

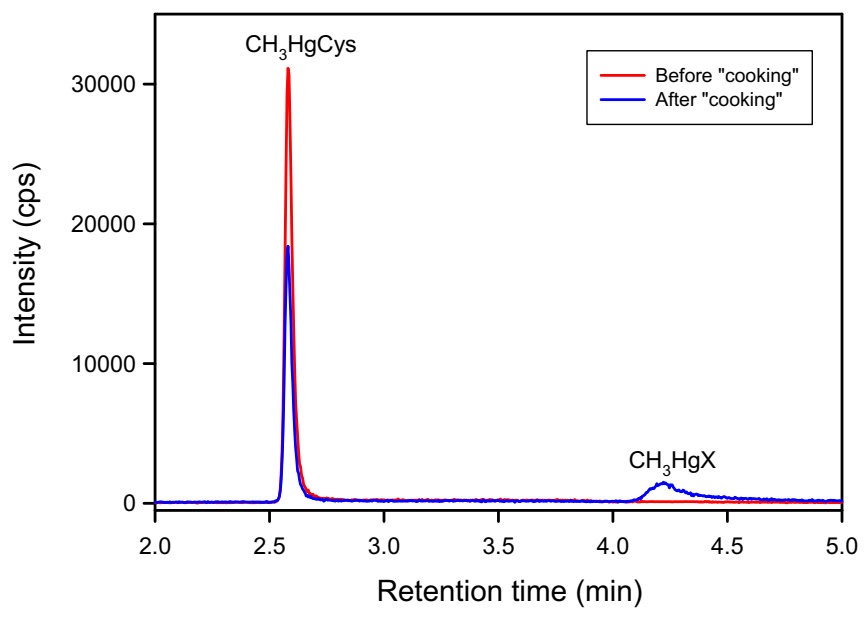

Fig. 4. Chromatogram of a $100 \mu \mathrm{g} \mathrm{L}^{-1}$ of $\mathrm{CH}_{3} \mathrm{HgCys}$ standard solution before and after being cooked $20 \mathrm{~min}$ in boiling water.

phytochelatins which prevented the translocation of MeHg. Since the $\mathrm{MeHg}$ solution was injected into the processed rice plant tissues, it may not reflect how MeHg is metabolized and translocated in rice plants in nature. Krupp et al. (2009) also did not study the MeHg speciation in rice grain, the edible tissue of the rice plant.

In nature, particularly in $\mathrm{Hg}$ mining areas, it is known that rice grain may contain elevated MeHg concentrations (Feng et al., 2008; Horvat et al., 2003; Qiu et al., 2008; Zhang et al., 2010). Although the mechanism of how $\mathrm{MeHg}$ is elevated in rice remains unknown, there is no evidence to suggest that $\mathrm{Hg}$ is methylated in vivo in rice grain or other tissues. The MeHg in rice grain is more likely originated from $\mathrm{MeHg}$ in rice paddy soil, which is translocated and accumulated during the growing season (Zhang et al., 2010). High $\mathrm{MeHg}$ concentrations were indeed reported in rice paddy soils in Hg mining areas (Feng et al., 2008; Horvat et al., 2003; Qiu et al., 2008), possibly due to the use of $\mathrm{Hg}$ contaminated water for irrigation and the anaerobic conditions created by the seasonal flooding during the rice growing period which favors $\mathrm{Hg}$ methylation.

To our knowledge, Fig. $2 \mathrm{~A}$ is the first analytical evidence showing the presence and dominance of MeHgCys in uncooked rice. It should be noted that the $\mathrm{CH}_{3} \mathrm{HgCys}$ detected in the uncooked rice extractant includes not only the "free" $\mathrm{CH}_{3} \mathrm{HgCys}$, but also the "bound" $\mathrm{CH}_{3} \mathrm{HgCys}$ residues released from the trypsin hydrolyzable proteins. These results are consistent with our earlier work on MeHg speciation in fish muscle (Lemes and Wang, 2009). However, while uncooked raw fish muscle is commonly consumed, very rare is uncooked rice grain consumed by humans. Instead, in almost all the cases rice is first cooked before consumption. As shown in Fig. 3, the cooking of rice with boiling water effectively removed most, if not all, of the $\mathrm{CH}_{3} \mathrm{HgCys}$.

The decomposition of MeHgCys during the cooking process is demonstrated by Figs. 3 and 4 . However, we were not able to deduct the decomposition product(s) of $\mathrm{CH}_{3} \mathrm{HgCys}$ in rice after the cooking. Since there is essentially no change in $\mathrm{MeHg}_{\mathrm{T}}$ after cooking, $\mathrm{CH}_{3} \mathrm{HgCys}$ must have been converted to other MeHg species, which unfortunately could not be identified by the current analytical technique due to the insufficient DL and matrix interference. The rice grains absorbed water and became puffy and sticky during cooking process, which led to the volume expansion. Therefore, less mass of the cooked rice had to be used for enzymatic hydrolysis to maintain the extraction efficiency of $\mathrm{Hg}$, which further limited the quantitation. In addition, rice is rich in carbohydrates, fat, proteins, vitamins, minerals and other nutrients. Due 
to the high temperature during the cooking process, the macromolecules in the rice became denatured and changed texture. Especially the starches in the rice created simpler mucilaginous saccharides during cooking, which thickened the extraction solution. More powerful techniques are thus needed to unambiguously identify and quantify the degradation products of $\mathrm{CH}_{3} \mathrm{HgCys}$ in cooked rice.

\section{Conclusions}

The recent discovery of $\mathrm{MeHg}$-enriched rice from $\mathrm{Hg}$ mining areas is one of the most significant findings in the study of $\mathrm{Hg}$ contamination (Feng et al., 2008; Horvat et al., 2003; Qiu et al., 2008; Zhang et al., 2010). A trypsin hydrolysis technique followed by HPLC-ICP-MS analysis showed that the MeHg in the uncooked white rice grown from a $\mathrm{Hg}$ mining area is almost exclusively present as $\mathrm{CH}_{3} \mathrm{HgCys}$, a complex that permits the transport of $\mathrm{MeHg}$ across the blood-brain and placental barriers. We further showed that cooking of rice effectively converts most, if not all, of the $\mathrm{CH}_{3} \mathrm{HgCys}$ to other forms of $\mathrm{MeHg}$, although the identity and toxicity of the degradation products remain unknown. These results provide an important first step toward the understanding of the source, translocation and human health implications of $\mathrm{MeHg}$ in rice, the staple food for a large fraction of the global population.

\section{Acknowledgement}

This work was financially supported by the Natural Sciences and Engineering Research Council of Canada (F.W.), the National Natural Science Foundation of P. R. China (20937002, G.J.), the State High Technological Development Plan of P.R. China (2009CB421605, G.J.), and the National High-tech Research and Development Program of China (2008AA06Z335, X.F.). We thank D. Armstrong for assistance in the laboratory analysis, and two anonymous reviewers for their constructive comments on an earlier version of this paper.

\section{Appendix. Supplementary material}

Supplementary data associated with this article can be found in the online version at doi:10.1016/j.envpol.2010.06.028.

\section{References}

CFIA, 2001. Canadian Guidelines for Chemical Contaminants and Toxins in Fish and Fish Products. Canadian Food Inspection Agency, Ottawa, ON, Canada.

Clarkson, T.W., 1993. Molecular and ionic mimicry of toxic metals. Ann. Rev. Pharmacol. Toxicol. 33, 545-571.

Clarkson, T.W., 1998. Human toxicology of mercury. J. Trace Elem. Exp. Med. 11, 303-317.

Feng, X., Li, P., Qiu, G., Wang, S., Li, G., Shang, L., et al., 2008. Human exposure to methylmercury through rice intake in mercury mining areas, Guizhou Province, China. Environ. Sci. Technol. 42, 326-332.

Harris, H.H., Pickering, I.J., George, G.N., 2003. The chemical form of mercury in fish. Science 301, 1203.

Horvat, M., Nolde, N., Fajon, V., Jereb, V., Logar, M., Lojen, S., et al., 2003. Total mercury, methylmercury and selenium in mercury polluted areas in the province Guizhou, China. Sci. Total Environ. 304, 231-256.

Krupp, E.M., Mestrot, A., Wielgus, J., Meharg, A.A., Feldmanna, J., 2009. The molecular form of mercury in biota: identification of novel mercury peptide complexes in plants. Chem. Comm. 28, 4257-4259.

Lemes, M., Wang, F., 2009. Methylmercury speciation in fish muscle by HPLCICP-MS following enzymatic hydrolysis. J. Anal. At. Spectrom. 24, 663-668.

Liang, L., Horvat, M., Bloom, N.S., 1994. An improved speciation method for mercury by GC/CVAFS after aqueous phase ethylation and room temperature precollection. Talanta 41, 371-379.

Liang, L., Horvat, M., Cernichiari, E., Gelein, B., Balogh, S., 1996. Simple solvent extraction technique of elimination of matrix interferences in the determination of methylmercury in environmental and biological samples by ethylationgas chromatography-cold vapor atomic fluorescence spectrometry. Talanta 43, 1883-1888.

Lockhart, W.L., Stern, G.A., Wagemann, R., Hunt, R.V., Metner, D.A., DeLaronde, J., et al., 2005. Concentrations of mercury in tissues of beluga whales (Delphinapterus leucas) from several communities in the Canadian Arctic from 1981 to 2002. Sci. Total Environ. 351/352, 391-412.

Mergler, D., Anderson, H.A., Chan, L.H.M., Mahaffey, K.R., Murray, M., Sakamoto, M., et al., 2007. Methylmercury exposure and health effects in humans: a worldwide concern. Ambio 36, 3-11.

Qiu, G.L., Feng, X.B., Li, P., Wang, S.F., Li, G.H., Shang, L.H., et al., 2008. Methylmercury accumulation in rice (Oryza sativa L.) grown at abandoned mercury mines in Guizhou, China. J. Agric. Food Chem. 56, 2465-2468.

Simmons-Willis, T.A., Koh, A.S., Clarkson, T.W., Ballatori, N., 2002. Transport of a neurotoxicant by molecular mimicry: the methylmercury-L-cysteine complex is a substrate for human L-type large neutral amino acid transporter (LAT) 1 and LAT2. Biochem. J. 367, 239-246.

USEPA, 1992. Guidelines for Exposure Assessment. Risk Assessment Forum. EPA/ 600/Z-92/001. U.S. Environmental Protection Agency, Washington, DC.

USEPA, 2001. Method 1630: Methyl Mercury in Water by Distillation, Aqueous Ethylation, Purge and Trap, and CVAFS. U.S. Environmental Protection Agency, Washington, DC.

WHO, 1990. Methylmercury. Environmental health Criteria 101. International Programme on Chemical Safety. World Health Organization, Geneva.

Zhang, H., Feng, X., Larssen, T., Shang, L., Li, P., 2010. Bioaccumulation of methylmercury versus inorganic mercury in rice (Oryza sativa L.) grain. Environ. Sci. Technol. 44, 4499-4504. 